\title{
Isolation of Carnobacterium piscicola and an unidentified Gram-positive bacillus from sexually mature and post-spawning rainbow trout Oncorhynchus mykiss
}

\author{
Clifford E. Starliper ${ }^{1}$, Emmett B. Shotts ${ }^{2}$, John Brown ${ }^{2}$ \\ ${ }^{1}$ National Fish Health Research Laboratory, Box 700, Kearneysville, West Virginia 25430, USA \\ ${ }^{2}$ Dept of Medical Microbiology, College of Veterinary Medicine, University of Georgia, Athens, Georgia 30602, USA
}

\begin{abstract}
Biochemical and electrophoretic studies were done on bacterial isolates collected from rainbow trout Oncorhynchus mykiss from 2 private hatcheries in the Pacific Northwest. USA. Five isolates originated from post-spawning mortalities and morbidities; 2 other isolates were obtained from reproductively active 17 mo old rainbow trout. After ${ }^{35}$ S-methionine-labeled protein lysates were prepared from each isolate, correlation coefficients of electrophoretic profiles were calculated for each pair of isolates using an automated microbiological identification system (AMBIS). The Gram-positive isolates appeared to represent 1 or possibly 2 genera: Carnobacterium and Lactobacillus. Five isolates were identified as C. piscicola and two $(106891,106892)$ did not correspond to any previously described species. Comparisons based upon correlation coefficients calculated for the 2 unidentified isolates and for biochemically similar strains, including C. piscicola (ATCC 15434), L. alimentarius (ATCC 29643) and $L$. homohiochi (ATCC 15434), resulted in values no greater than 0.792 . This dissimilarity suggests that the 2 unidentified isolates represent a different biotype of $C$. piscicola or a previously undescribed species of Lactobacillus.
\end{abstract}

\section{INTRODUCTION}

For the past several years, 2 privately owned trout facilities in Idaho have experienced a chronic disease problem in their adult fish. Although significantly high mortality has not occurred, low level mortality has been repeatedly observed ongoing in post-spawned fish and fish of spawning age, primarily among females. Some mortality resulting from handling during the spawning process is not unusual; however, the consistent low level losses over a number of years generated an interest to determine a cause. Health inspections and post-mortem examinations implicated a Grampositive bacillus as the etiological agent. Because of the hatcheries' geographical location in a region where Renibacterium salmoninarum, causative agent of bacterial kidney disease, is enzootic, and because of an increased awareness of the diversity of the Gram-positive bacilli associated with fish (Hiu et al.
1984, Collins et al. 1987), a comprehensive characterization of the Gram-positive bacteria associated with the disease was undertaken.

\section{MATERIALS AND METHODS}

During a recent 16 mo period, bacterial isolates were collected from rainbow trout Oncorhynchus mykiss at 2 facilities, one a brood stock station and the other a rearing facility. Four isolates were obtained from moribund post-spawning females, and 1 from a dead postspawning female. All of these fish were between 2 and $5 \mathrm{yr}$ of age. Two additional isolates came from the rearing facility and involved 17 mo old reproductively active females that otherwise appeared to be healthy.

The brood stock station was experiencing a chronic post-spawning mortality problem. Daily mortality ranged from 1 to 6 fish (in a population of nearly 
20000). A Gram-negative bacteremia was concurrently detected in the population from which Isolate 335871 originated.

Bacterial samples were collected from the kidney, spleen, swimbladder and intestine of moribund fish. Tissue samples were streaked onto blood agar and tryptic soy agar. Plates were incubated at 15 to $20^{\circ} \mathrm{C}$ and periodically examined for growth. A list of the isolates obtained is given in Table 1. Reference strains included Lactobacillus piscicola (ATCC 35586), L. alimentarius (ATCC 29643), and L. homohiochi (ATCC 15434). They were selected for the electrophoretic analysis because they were the most similar, biochemically, to the 2 isolates $(106891,106892)$ that did not correspond to any described species.

Bacterial strains were examined for purity prior to characterization by streaking onto $5 \%$ bovine blood agar. Colonies were reinoculated onto blood agar and brain heart infusion agar plates to obtain bacterial growth for further biochemical and morphological studies. Unless otherwise indicated, incubation was at $30^{\circ} \mathrm{C}$, the temperature which produced the most luxurious growth. The initial characteristics determined were those of diagnostic value for the genera Carnobacterium, Lactobacillus, Lactococcus and Vagococcus: the TSI reaction, Gram reaction, catalase and cytochrome oxidase production, hemolysis on blood agar, nitrate reduction, and motility (by microscopic examination of a $24 \mathrm{~h}$ brain heart infusion broth culture) (Schleifer et al. 1985, Kandler \& Weiss 1986, Collins et al. 1987,1989 ).

Determination of lactic acid production as a product of hexose fermentation in homofermentative or heterofermentative proportions was accomplished on HHD agar plates (McDonald et al. 1987). Individual colonies of homofermentative strains were blue as a result of the high concentrations of lactic acid produced from fermentation of the hexose (fructose) present in HHD agar. Colonies of heterofermentative strains remained white.

Production of acid from a number of carbohydrates was examined utilizing purple broth base medium

Table 1. Lactobacillus/Carnobacterium isolates from rainbow trout Oncorhynchus mykiss originating from a broodstock station or rearing facility in Idaho, USA

\begin{tabular}{llll|}
\hline Isolate & Facility & Tissue & Year \\
\hline 335871 & Broodstock & Swimbladder & 1987 \\
00188 & Rearing & Kidney & 1988 \\
01488 & Rearing & Intestine & 1988 \\
27488 & Broodstock & Kidney & 1988 \\
032891 & Broodstock & Kidney & 1989 \\
106891 & Broodstock & Kidney & 1989 \\
106892 & Broodstock & Kidney & 1989 \\
\hline
\end{tabular}

with each sugar filter-sterilized and added to yield a $1 \%$ final concentration. Carbohydrates examined were D-glucose, D-mannitol, D-ribose, cellobiose, lactose, D-sorbitol, esculin, salicin, sucrose, D-mannose, trehalose, rhamnose, raffinose, melibiose, L-arabinose, fructose, glycerol, erythritol, inositol, dulcitol, L-sorbose, adonitol, D-xylose, D-galactose, maltose, D-melezitose, and D-gluconic acid. Presence of lysine and ornithine decarboxylase and of arginine dehydrolase was determined in Moeller basal medium with $1 \%$ of the L-form amino acid. Tests previously described by Koneman et al. (1983) and MacFaddin (1980) were done to assess utilization of citrate (Simmon's) and malonate as sole carbon sources, production of acetoin from glucose, hydrolysis of starch, action in litmus milk medium, oxidation of gluconate to reducing compounds, methyl red reaction, and the presence of urease, phenylalanine deaminase and $\beta$-galactosidase. Production of ammonia from arginine was detected using the method of Niven et al. (1942). Growth at 4, 15, 37 and $42{ }^{\circ} \mathrm{C}$ was determined by inoculating test bacteria onto blood agar plates. The ability of the isolates to grow in nutrient broth in the presence of various concentrations $(6.5,7.0,8.0,9.0$ and $10.0 \%)$ of sodium chloride was tested, as was their ability to grow on MacConkey agar, tomato juice agar (TJA; Kulp \& White 1932) and on selective lactobacillus isolation medium (SL; Rogosa et al. 1951).

Analysis of the electrophoretic profiles of the isolates was accomplished using an automated microbiological identification system (AMBIS; Automated Microbiology Systems, Inc., San Diego, CA, USA). Use of the AMBIS requires metabolic labeling of the bacterial proteins with a beta-emitting radioactive isotope such as ${ }^{35} \mathrm{~S}$ or ${ }^{14} \mathrm{C}$. Since a detailed description of the AMBIS is presented elsewhere (Hook et al. 1987, Tabaqchali et al. 1987), the methodology is only briefly outlined here. Bacterial strains were grown on brain heart infusion agar (BHIA; DIFCO) for $48 \mathrm{~h}$. Several colonies were picked and used to inoculate $50 \mu \mathrm{l}$ of methioninedeficient amino acid assay medium (DIFCO) supplemented with $10 \mu \mathrm{Ci}^{35} \mathrm{~S}$-methionine (Amersham Corp., Arlington Heights, IL, USA). Following incubation for $48 \mathrm{~h}$ at $30^{\circ} \mathrm{C}$, whole cell lysates were prepared by adding $50 \mu \mathrm{l}$ of $2 \times$ concentrated sample lysis buffer. The $100 \mu \mathrm{l}$ of volume was transferred to a $0.5 \mathrm{ml} \mathrm{micro-}$ fuge tube filled with $0.15 \mathrm{~mm}$ zirconium oxide beads and placed on a mini-beadbeater (Biospec Products, Bartlesville, OK, USA) for $3 \mathrm{~min}$. The sample was removed from the beads by centrifugation, boiled for 2 min, and then subjected to sodium dodecyl sulphatepolyacrylamide gel electrophoresis (SDS-PAGE) using a $12.5 \%$ gel. After electrophoresis, gels were dried and scanned (AMBIS beta scanner). The protein band profile of each lane was filed in a computer as the 
number of counts per minute of isotope decay for each specific region of the lane scanned. Three lanes of known molecular weight standards were included on each gel to allow for molecular weight determination of a particular protein(s) of interest and also to serve as gel standards which were normalized to a previously filed absolute standard. Sample lanes were then normalized to the gel-specific standard lanes. Normalization was done to reduce gel to gel variability. Normalized lanes were referred to as 'adjusted lanes'.

Typically, a lane profile is 504 pixels in length. However, only the region between 60 and 300 pixels (corresponding to a molecular weight range of 242 Da to $14.8 \mathrm{kDa}$, respectively) was considered so as to eliminate those regions of the gel containing unincorporated isotope. Qualitative and quantitative differences in proteins for each pair of isolates were evaluated using the Pearson product-moment correlation coefficient algorithm (Sneath \& Sokal 1973). The similarity of any 2 isolates increased as the value for $r$ approached 1 .

Pathogenicity of the fish isolates, including the reference strain of Lactobacillus pisicola (ATCC 35586), was assessed by intraperitoneal (ip) injection and waterborne-exposure. Eighteen $20 \mathrm{~g}$ rainbow trout were challenged in each experiment. Fish were maintained in tanks containing $35 \mathrm{l}$ of water with a flow of $1 \mathrm{lmin}^{-1}$ at $12^{\circ} \mathrm{C}$. Each isolate was grown in $11 \mathrm{BHIB}$ for $24 \mathrm{~h}$ at 25 to $30^{\circ} \mathrm{C}$. For ip injections, fish were anesthetized and inoculated with $0.1 \mathrm{ml}$ of broth containing $1.3 \times 10^{8} \mathrm{CFU} \mathrm{ml}^{-1}$. Waterborne-challenge was done by transferring the fish to $1 \mathrm{l}$ of broth culture $\left(1.3 \times 10^{7} \mathrm{CFU} \mathrm{ml} \mathrm{m}^{-1}\right)$ for $10 \mathrm{~min}$ and then returning them to their tanks. Controls were exposed to sterile BHIB using the same procedures. Seven days after challenge, 5 fish were removed from each tank and samples of their kidney tissue were streaked onto BHIA plates. After $30 \mathrm{~d}$, the remaining fish were removed; their kidneys were excised, homogenized, and diluted in sterile $0.85 \%$ saline. Plate counts on the dilutions were done to determine the number of CFU g ${ }^{-1}$ of tissue. During the period of experimental infection, isolations were made from mortalities by streaking kidney tissue onto BHIA.

\section{RESULTS}

External signs usually seen in the moribund females included lethargy, loss of appetite, a general darkening of the body surface and an occasional blister-like lesion. Necropsy revealed the following internal signs: abnormally high amounts of ascitic fluid and in some cases, bloody ascitic fluid; swollen kidney, liver and spleen; and varying degrees of hemorrhage in the liver, swimbladder, musculature, and lower intestine. The extent of clinical signs varied from none (there were apparent carrier fish such as the one from which Isolate 01488 originated) to that of the post-spawned broodstock fish which displayed most or all of the signs mentioned. Bacterial isolations were made from several internal sites (including the swimbladder, kidney, lower intestine, ascites fluid, liver and spleen) in those fish having the more severe manifestations of clinical disease.

Two isolates (00188 and 01488) were recovered during routine fish health examinations of 17 mo old fish culled from the rearing facility. Fish were transferred to the egg-taking station only after each lot had passed numerous fish health examinations and were found to be free of certifiable pathogens. Fish lots were inspected periodically by examining samples of 30 fish. The group of fish from which these 2 isolates were obtained were classified as reproductively active and contained mature males and overripe females. Hatchery records indicated no abnormal mortality in this population. Isolate 01488 was made from the lower intestine, whereas Isolate 00188 came from a swollen kidney. A bacteremia of minor significance due to a Gram-negative bacterium occurred in some fish in this group but was not present in the individuals that yielded Isolates 00188 and 01488 .

None of the isolates grew at 4 or at $42^{\circ} \mathrm{C}$. All isolates grew at $15^{\circ} \mathrm{C}$, and growth at $37^{\circ} \mathrm{C}$ varied (Table 2).

Normal atmospheric conditions were sufficient for primary isolation, subsequent subculturing and biochemical tests. Cells were Gram-positive, non-sporeforming rods, ca $0.5 \mu \mathrm{m}$ by 1 to $1.5 \mu \mathrm{m}$. Good growth was obtained on culture media such as blood agar and brain heart infusion agar. After $48 \mathrm{~h}$ incubation on blood agar plates, colonies were approximately $1 \mathrm{~mm}$ in diameter, white, rounded and smooth. Colonial consistency was creamy rather than friable or mucoid. With 2 of the isolates (106891 and 106892), colony morphology was pleomorphic. At $48 \mathrm{~h}$ incubation, 2 colony sizes were apparent with each of these 2 isolates. One was typically $1 \mathrm{~mm}$ in diameter and the other, 2- to 3-fold larger. The colony pleomorphism increased with additional incubation time. Physiological and biochemical differences between the 2 colony sizes were not demonstrable, and mixed sizes were present after repeated streaking of individual small or large colonies.

All isolates were $\alpha$-hemolytic, cytochrome oxidase negative and non-motile. They failed to reduce nitrates and gave an A/A TSI reaction with no $\mathrm{H}_{2} \mathrm{~S}$ being produced. Six isolates (335871, 01488, 106892, 00188, 27488,032891 ) were catalase positive. Species of the genera Carnobacterium, Lactococcus, Vagococcus and most of the Lactobacillus spp. are catalase negative. 
Table 2. Variable biochemical and physiological reactions of Lactobacillus/Carnobacterium isolates from rainbow trout. Results reported as: no. positive/no. tested ${ }_{i},+_{i}$ w (weakly positive); or NA (not available)

\begin{tabular}{|c|c|c|c|c|}
\hline & \multicolumn{2}{|c|}{ Published results ${ }^{a}$} & \multicolumn{2}{|c|}{ Present study } \\
\hline & $\begin{array}{l}\text { Lactobacillus } \\
\text { piscicola }\end{array}$ & $\begin{array}{c}\text { Carnobacterium } \\
\text { piscicola }\end{array}$ & $\begin{array}{r}00188 \\
335871 \\
01488 \\
27488 \\
032891\end{array}$ & $\begin{array}{l}106891 \\
106892\end{array}$ \\
\hline Catalase & $0 / 17$ & - & $5 / 5$ & $1 / 2$ \\
\hline Arginine dehydrolase & NA & + & $5 / 5$ & - \\
\hline Gluconate & NA & NA & $5 / 5$ & - \\
\hline $\mathrm{NH}_{3}$ from arginine & $17 / 17$ & NA & $5 / 5$ & - \\
\hline $\mathrm{ONPG}^{\mathrm{b}}$ & $10 / 17$ & + & $3 / 5$ & - \\
\hline \multicolumn{5}{|l|}{ Acid from: } \\
\hline D-mannitol & $15 / 17$ & + & $4 / 5$ & + \\
\hline Lactose & $6 / 17$ & + & $4 / 5$ & - \\
\hline D-sorbitol & $0 / 17$ & - & $4 / 5$ & - \\
\hline Raffinose & $5 / 17$ & - & $2 / 5$ & - \\
\hline Melibiose & $5 / 17$ & - & $2 / 5$ & - \\
\hline L-arabinose & $0 / 17$ & + & $0 / 5$ & $w$ \\
\hline Glycerol & $14 / 17$ & NA & $5 / 5$ & - \\
\hline Inositol & $0 / 17$ & - & $1 / 5$ & - \\
\hline D-galactose & $11 / 17$ & + & $4 / 5$ & - \\
\hline Melezitose & $2 / 17$ & + & $4 / 5$ & $w$ \\
\hline \multicolumn{5}{|l|}{ Growth: } \\
\hline Tomato juice agar & NA & NA & $5 / 5$ & - \\
\hline $37^{\circ} \mathrm{C}$ & NA & + & $5 / 5$ & - \\
\hline $7 \% \mathrm{NaCl}$ & NA & + & $5 / 5$ & $1 / 2$ \\
\hline $8 \% \mathrm{NaCl}$ & NA & - & $5 / 5$ & $1 / 2$ \\
\hline $9 \% \mathrm{NaCl}$ & NA & - & $3 / 5$ & - \\
\hline
\end{tabular}

although catalase positive reactions have been reported for L. plantarum (Dacre \& Sharpe 1956, Whittenbury 1960), L. divergens (Holzapfel \& Gerber 1983) and L. mali (Carr \& Davies 1970). All isolates fermented D-glucose, sucrose, trehalose, fructose, salicin, D-ribose, cellobiose, D-mannose, D-gluconic acid and maltose, reduced litmus or fermented lactose (white color) in litmus milk, were esculin positive, grew in nutrient broth containing $6.5 \% \mathrm{NaCl}$, and produced sufficiently acidic conditions for a positive methyl red reaction. None of the isolates produced acid from rhamnose, erythritol, L-sorbose, adonitol, D-xylose, or dulcitol and all were negative for the following tests: lysine and ornithine decarboxylase, phenylalanine deaminase, Simmons citrate, urea, malonate, VogesProskauer, and starch hydrolysis. None of the isolates grew on Lactobacillus-selective medium (acetate medium), MacConkey agar or in nutrient broth containing $10 \% \mathrm{NaCl}$.

Five of the isolates $(00188,335871,01488,27488$, 032891) were identified as Carnobacterium piscicola (formerly Lactobacillus piscicola) based upon the similarities of the biochemical and physiological reactions with those reported by Hiu et al. (1984) and Collins et al. (1987). Furthermore, these isolates produced mainly lactic acid from hexoses (blue colonies on HHD medium) and were able to utilize pentoses, characteristics which are consistent with facultatively heterofermentative lactobacilli (Kandler \& Weiss 1986).

Isolates 106891 and 106892 differed from Carnobacterium piscicola in several of the biochemical tests (Table 2). They also differed in their biochemical characteristics from species of Lactococcus and Vagococcus including production of acid from various sugars, starch hydrolysis, ONPG, Voges-Proskauer, motility, arginine dehydrolase, and growth in various concentrations of $\mathrm{NaCl}$ (Schleifer et al. 1985, Collins et al. 1989, Wallbanks et al. 1990, Williams et al. 1990). A comparison of the biochemical results for these 2 isolates with those of previously described Lactobacillus spp. (Kandler \& Weiss 1986) revealed L. alimentarius and $L$. homohiochi as the most similar organisms. To further examine similarities of these isolates, correlation coefficients ( $r$ values) of the 
Table 3. Relationships among fish isolates and reference cultures based on electrophoretic profiles released from cells on lysis. Adjusted lane profile correlation coefficient ( $r$ ) for each pair of isolates using the Pearson product-moment method. Mean (SE) calculated for 3 gels. ATCC 35586: Carnobacterium piscicola; ATCC 29643: Lactobacillus alimentrius; ATCC 15434: L. homohiochi

\begin{tabular}{|c|c|c|c|c|c|c|c|c|c|}
\hline Isolate & $\begin{array}{l}\text { ATCC } \\
35586\end{array}$ & $\begin{array}{l}\text { ATCC } \\
29643\end{array}$ & $\begin{array}{l}\text { ATCC } \\
15434\end{array}$ & 106891 & 106892 & 335871 & 00188 & 01488 & 032891 \\
\hline ATCC 35586 & 1 & $\begin{array}{c}0.531 \\
(0.234)\end{array}$ & 0.760 & $\begin{array}{c}0.678 \\
(0.213\}\end{array}$ & $\begin{array}{c}0.471 \\
(0.065)\end{array}$ & $\begin{array}{c}0.924^{\circ} \\
(0.063)\end{array}$ & $\begin{array}{r}0.877^{\circ} \\
(0.031)\end{array}$ & $\begin{array}{c}0.933^{\circ} \\
(0.042)\end{array}$ & $\begin{array}{r}0.952^{\circ} \\
(0.028)\end{array}$ \\
\hline ATCC 29643 & & 1 & 0.497 & $\begin{array}{c}0.745 \\
(0.334)\end{array}$ & $\begin{array}{c}0.792 \\
(0.116)\end{array}$ & $\begin{array}{c}0.662 \\
(0.164)\end{array}$ & $\begin{array}{c}0.571 \\
(0.221)\end{array}$ & $\begin{array}{c}0.635 \\
(0.149)\end{array}$ & $\begin{array}{c}0.629 \\
(0.202)\end{array}$ \\
\hline $\operatorname{ATCC} 15434^{\mathrm{b}}$ & & & 1 & 0.556 & 0.315 & 0.752 & 0.695 & 0.617 & 0.740 \\
\hline 106891 & & & & 1 & $\begin{array}{c}0.803 \\
(0.155)\end{array}$ & $\begin{array}{c}0.778 \\
(0.054)\end{array}$ & $\begin{array}{c}0.684 \\
(0.183)\end{array}$ & $\begin{array}{c}0.707 \\
(0.119)\end{array}$ & $\begin{array}{c}0.688 \\
(0.180)\end{array}$ \\
\hline 106892 & & & & & 1 & $\begin{array}{c}0.559 \\
(0.108)\end{array}$ & $\begin{array}{c}0.463 \\
(0.016)\end{array}$ & $\begin{array}{c}0.568 \\
(0.166)\end{array}$ & $\begin{array}{c}0.530 \\
(0.143)\end{array}$ \\
\hline 335871 & & & & & & 1 & $\begin{array}{r}0.930^{\circ} \\
(0.032)\end{array}$ & $\begin{array}{c}0.931^{\circ} \\
(0.044)\end{array}$ & $\begin{array}{r}0.925^{\circ} \\
(0.037)\end{array}$ \\
\hline 00188 & & & & & & & 1 & $\begin{array}{c}0.895^{\circ} \\
(0.040)\end{array}$ & $\begin{array}{c}0.868 \\
(0.014)\end{array}$ \\
\hline 01488 & & & & & & & & 1 & $\begin{array}{c}0.948^{\circ} \\
(0.009)\end{array}$ \\
\hline 032891 & & & & & & & & & 1 \\
\hline
\end{tabular}

${ }^{35} \mathrm{~S}$-methionine protein profiles using the AMBIS were obtained (Table 3). Correlation coefficients ( $r$ values) of Isolate 106891 were 0.745 and 0.556 for L. alimentarius and $L$. homohiochi respectively, and $r$ values for Isolate 106892 were 0.792 and 0.315 respectively. For replicates of 3 , isolates are considered highly related at the $\alpha=0.05$ significance level, if $r \geq 0.87$ (Fisher \& Yates 1949). Neither isolate (106891, 106892) had an $r>0.678$ with Carnobacterium piscicola.

One mortality occurred as a result of the bacterial challenges, on Day 4 in the ip-injected group with Isolate 27488. Reisolation of the bacterium from the kidney was successful.

Table 4. Reisolation of Lactobacillus/Carnobacterium spp. $30 \mathrm{~d}$ after challenge. Values shown are number of fish from which the bacterium was reisolated and, in parentheses, mean CFU $g^{-1}$ kidney tissue. 13 fish per group

\begin{tabular}{|c|c|c|}
\hline Isolate & Waterborne & Ip-injection \\
\hline 01488 & 0 & $7\left(6.5 \times 10^{2}\right)$ \\
\hline 00188 & 0 & $8\left(2 \times 10^{2}\right)$ \\
\hline 032891 & $3\left(3 \times 10^{2}\right)$ & $8 \quad\left(2.67 \times 10^{2}\right)$ \\
\hline 27488 & $2\left(2 \times 10^{2}\right)$ & $10\left(2.53 \times 10^{3}\right)$ \\
\hline 335871 & $3\left(6 \times 10^{2}\right)$ & $7\left(5 \times 10^{2}\right)$ \\
\hline 106891 & $0 \quad-$ & $0 \quad-$ \\
\hline 106892 & $4\left(4.5 \times 10^{2}\right)$ & 0 \\
\hline ATCC 35586 & 0 & $8 \quad\left(6.75 \times 10^{2}\right)$ \\
\hline Control & 0 & 0 \\
\hline
\end{tabular}

Seven days following challenge, 5 fish from each challenge group were sacrificed and their kidneys cultured for the challenge organism. Bacteria were not isolated from the group waterborne-challenged with Isolate 00188 nor from the groups waterborne- or ip-challenged with Isolates 106891 and 106892. Of the remaining groups of fish (i.e. those challenged with Isolates 01488, 00188, 032891, 27488, 335871 and ATCC 35586), bacteria were recovered from all groups: $56 \%$ of the fish from the waterbornechallenges and $97 \%$ from the ip-injected groups yielded the challenge bacteria. Results of reisolation attempts from the fish remaining at the end of the experiment are given in Table 4.

\section{DISCUSSION}

Lactobacillus spp. have been isolated from a variety of seemingly healthy fish species (Kvasnikov et al. 1977, Knochel 1981, Humphrey et al. 1987). Studying 350 fish including 336 of several trout species in waters around Ontario, Canada, Evelyn \& McDermott (1961) showed that $19 \%$ of the fish yielded Lactobacillus. Of the fish examined, $89 \%$ appeared normal and healthy.

Other reports demonstrate that Lactobacillus is often associated with disease in fishes. Rucker et al. (1953) reported a chronic disease resulting in mortality in coho salmon Oncherhynus kisutch in the Pacific north- 
western United States. High mortality in female broodstock due to a Lactobacillus was reported to have occurred on more than one occasion at the Hot Creek Hatchery, California, USA, (Ross \& Toth 1974). Because the mortality due to Lactobacillus appeared to be related to the stress of spawning, Ross \& Toth (1974) attempted to produce the disease experimentally in post-spawned rainbow trout. Herman et al. (1985) also attempted to reproduce the disease in juvenile rainbow trout. Both groups of workers were unable to reproduce the disease or mortality following intraperitoneal injection. Other reports describe the isolation of Lactobacillus from broodstock fish following the handling and stress of spawning (Cone 1982, Hiu et al. 1984, Herman et al. 1985). The present study, along with these previous reports, indicate that disease due to this group of organisms is apparently a result of an opportunistic organism of low virulence because most isolations have been made from fish experiencing stress due to spawning. These results agree with those of Michel et al. (1986) for isolates from Europe who also showed the strains to possess low virulence.

The term pseudo-kidney disease has been used for lactobacillosis and was used to distinguish the disease from bacterial kidney disease, due to Renibacterium salmoninarum which causes high mortality in all ages of salmonid fishes. Although both diseases are caused by Gram-positive rods, $R$. salmoninarum is much more fastidious, has an absolute requirement of cysteine for growth and grows optimally at 15 to $18^{\circ} \mathrm{C}$, whereas Lactobacillus spp. from fish grow on many routine nonselective media and appear to grow best at $30^{\circ} \mathrm{C}$. In our studies, more luxurious growth occurred when glucose or fructose (about $1 \% \mathrm{w} / \mathrm{v}$ ) was used to supplement a medium not containing a hexose. This may be a consideration when attempts to isolate the organism are to be made.

The bacterial pathogen causing the disease lactobacillosis in salmonids was first named Lactobacillus piscicola by Hiu et al. (1984). On the basis of a comparative study involving certain Lactobacillus spp. frequently seen in poultry and also including L. piscicola, Collins et al. (1987) proposed the new generic name Carnobacterium for this group of bacteria, which they considered atypical Lactobacillus. Two characteristics for which L. piscicola was considered atypical of the genus included the lack of growth on the selection medium and the production of oleic acid instead of vaccenic acid as a major cellular fatty acid. Both fatty acids are 18 carbon and mono-unsaturated, but differ in the unsaturated position. The phylogenetic distinction made between these 2 genera (Lactobacillus and Carnobacterium) has recently been confirmed following comparisons of the homogeneity of the 16S rRNA sequences in the isolates (Wallbanks et al. 1990).
Slight differences are noted between results for Carnobacterium piscicola isolates of our study and those reported for C. piscicola by Collins et al. (1987) Those differences include acid production from sorbitol and gluconic acid by our $C$. piscicola isolates, the production of catalase, and negative Voges-Proskauer test after 3 wk incubation (Barritt 1936). In another study, Herman et al. (1985) reported mortality due to a Lactobacillus $\mathrm{sp}$. in brood stock rainbow trout following spawning. This bacterium was also sorbitol positive and Voges-Proskauer negative.

Six of the isolates in this study were shown to produce catalase. Two apparently distinct $\mathrm{H}_{2} \mathrm{O}_{2}$-splitting activities occur within the lactic acid bacteria (Whittenbury 1960, Johnson \& Delwiche 1962). One is a hemeor hematin-containing catalase activity which utilizes the iron-protoporphyrin complex as a coenzyme and results in active catalase ('classical catalase'). The other does not require hematin and has been termed pseudocatalase activity (Whittenbury 1964). Although it is established that 2 types of catalases exist within the lactic acid bacteria, there are conflicting reports as to whether both activities may be possessed by the same organism (Whittenbury 1964, Johnson \& Delwiche 1965). The isolates in our study which were catalase positive (335871, 01488, 106892, 00188, 27488 , 032891) were demonstrated to be of the hematin-requiring type of catalase activity assessed by the method of Whittenbury (1964). Catalase activity was also demonstrated by Lactobacillus piscicola ATCC 35586 and shown to be a hematin-requiring enzyme. When grown on 0.5 or $1 \%$ glucose nutrient medium, all strains were catalase negative, indicating a lack of pseudocatalase activity. However, when they were grown on heated blood agar which contained $1 \%$ glucose, catalase activity was present. With regard to the latter medium, the catalase activity of the red blood cells is destroyed by defibrination and subsequent heating, but the necessary coenzyme, hematin, is retained. The foregoing results indicate that in reporting catalase results for this group of bacteria it is important to specify the medium used in the test.

To conclude, our studies confirmed that Carnobac terium piscicola (formerly Lactobacillus piscicola) was the organism most frequently (5 of 7 isolates) recovered from sexually mature and post-spawning trout, some of which showed signs of a disease that has been referred to in the past as pseudo-kichney disease or lactobacillosis. In addition, and consistent with the experience of others, the organism showed low virulence in challenge tests with rainbow trout, once again suggesting that it is likely only to cause problems in severely stressed fish. Two of the 7 isolates collected in the study also proved to be Gram-positive bacilli of low 
virulence; they appeared to be identical to each other but could not be identified. The existence of these unidentified isolates in post-spawned fish suggests that Gram-positive bacilli other than Carnobacterium piscicola may also be involved in causing mortalities in highly stressed salmonids and indicates that further work on such organisms is needed.

\section{LITERATURE CITED}

Barritt, M. M. (1936). The intensification of Voges-Proskauer reaction by the addition of $\alpha$-napthol. J. Path. Bact. 42: $441-454$

Carr, J. G., Davies, P. A. (1970). Homofermentative Lactobacilli of ciders including Lactobacillus mali nov. spec. J appl. Bact. 33: 768-774

Collins, M. D., Ash, C., Farrow, J. A. E., Wallbanks, S., Williams, A. M. (1989). 16S Ribosomal ribonucleic acid sequence analyses of Lactococci and related taxa. Description of Vagococcus fluvialis gen. nov., sp. nov. J. appl. Bact. 67: 453-460

Collins, M. D., Farrow, J. A. E., Phillips, B. A., Ferusu, S., Jones, D. (1987). Classification of Lactobacillus divergens, Lactobacillus piscicola, and some catalasenegative, asporogenous, rod-shaped bacteria from poultry in a new genus, Carnobacterium. Int. J. Syst. Bact. 37: $310-316$

Cone, D. K. (1982). A Lactobacillus sp. from diseased female rainbow trout, Salmo gairdneri Richardson, in Newfoundland, Canada. J. Fish Dis. 5: 479-485

Dacre, J. C., Sharpe, M. E. (1956). Catalase production by Lactobacilli. Nature, Lond. 178: 700

Evelyn, T. P. T., McDermott, L. A. (1961), Bacteriological studies of fresh-water fish. I. Isolation of aerobic bacteria from several species of Ontario fish. Can. J. Microbiol. 7. $375-382$

Fisher, R. A., Yates, F. (1949). Statistical tables for biological. agricultural and medical research. Hafner Publishing $\mathrm{Co}$. Inc., New York

Herman, R. L., McAllister, K., Bullock, G. L., Shotts, E. B. Jr (1985). Postspawning mortality of rainbow trout (Salmo gairdneri) associated with Lactobacillus. J. Wildl. Dis. 21: $358-360$

Hiu, S. F., Holt, R. A., Sriranganathan, N., Seidler, R. J., Fryer, J. L. (1984). Lactobacillus piscicola, a new species from salmonid fish. Int. J. Syst. Bacteriol. 34: 393-400

Holzapfel, W. H., Gerber, E. S. (1983). Lactobacillus divergens sp. nov., a new heterofermentative Lactobacillus species producing $L(+)$-Lactate. Syst. appl. Microbiol. 4: 522-534

Hook, L. A., Bloch, P. L., Kohlenberger, R. W., Kinningham, P. A. (1987). Automated microbial identification system for computer-programmed analysis of radiolabeled protein banding patterns. Dev. Ind. Microbiol. 28: 149-160

Humphrey, J. D., Lancaster, C. E., Gudkovs, N., Copland, J. W. (1987). The disease status of Australian salmonids: bacteria and bacterial diseases. J. Fish Dis. 10: 403-410

Johnston, M. A., Delwiche, E. A. (1962). Catalase of the Lactobacillaceae. J. Bacteriol. 83: 936-938

Johnston, M. A., Delwiche, E. A. (1965). Distribution and characteristics of the catalases of Lactobacillaceae. J. Bacteriol. 90:347-351

Kandler, O., Weiss, N. (1986). Regular, nonsporing grampositive rods. In: Sneath, P. H. A., Mair, N. S., Sharpe, M. E., Holt, J. G. (eds.) Bergey's manual of systematic bacteriology, Vol. 2. Williams and Wilkins, Baltimore, p. $1208-1260$

Koneman, E. W., Allen, S. D., Dowell, V R. Jr, Sommers, H. M., (eds.) (1983). Color atlas and textbook of diagnostic microbiology, 2nd edn. J. P. Lippincott Co., Philadelphia

Knochel, S. (1981). Occurrence and some characteristics of Lactobacillus spp. isolated from fish. J. appl. Bacteriol. 51: $\mathrm{x}$

Kulp, W. L., White, V. (1932). A modified medium for plating Lactobacillus acidophilus. Science 66: 17-18

Kvasnikov, E. I., Kovalenko, N. K., Materinskaya, L. G. (1977). Lactic acid bacteria of freshwater fish. Microbiology 46 : $619-624$

MacFaddin, J. F. (ed.) (1980). Biochemical tests for identification of medical bacteria, 2nd edn. Williams and Wilkins, Baltimore

McDonald, L. C., McFeeters, R. F., Daeschel, M. A., Fleming, H. P. (1987). A differential medium for the enumeration of homofermentative and heterofermentative lactic acid bacteria. Appl environ. Microbiol. 53: 1382-1384

Michel, C., Faivre, B., Kerouault, B. (1986). Biochemical identification of Lactobacillus piscicola strains from France and Belgium. Dis. aquat. Org. 2: 27-30

Niven, C. F. Jr, Smiley, K. L., Sherman, J. M. (1942). The hydrolysis of arginine by streptococci. J. Bacteriol. 43: $651-660$

Rogosa, M., Mitchell, J. A., Wiseman, R. F. (1951). A selective medium for the isolation and enumeration of oral and fecal Lactobacilli. J. Bacteriol. 62; 132-133

Ross, A. J., Toth, R. J. (1974). Lactobacillus - a new fish pathogen? Progressive Fish Culturist 36: 191

Rucker, R. E., Earp, B. J., Ordal, E. J. (1953). Infectious diseases of Pacific salmon. Trans. Am. Fish. Soc. 83: 297-312

Schleifer, K. H., Krans, J., Dvorak, C., Kilpper-Baltz, R., Collins, M. D., Fischer, W. (1985). Transfer of Streptococcus lactis and related streptocci to the genus Lactococcus gen. nov. System. Appl. Microbiol. 6: 183-195

Sneath, P. H. A., Sokal, R. R. (eds.) (1973). Numerical taxonomy: the principles and practice of numerical classification. W. H. Freeman and Co., San Francisco

Tabaqchali, S., Silman, R., Holland, D. (1987). Automation in clinical microbiology: a new approach to identify microorganisms by automated pattern matching of proteins labelled with ${ }^{35}$ S-methionine. J. Clin. Pathol. 40: 1070-1087

Wallbanks, S., Martinez-Murcia, A. J., Fryer, J. L., Phillips, B. A., Collins, M. D. (1990). 16S rRNA Sequence determination for members of the genus Carnobacterium and related lactic acid bacteria and description of Vagococcus salmoninarum sp. nov. Int. J. Syst. Bact. 40:224-230

Whittenbury, R. (1960). Two types of catalase-like activity in lactic acid bacteria. Nature, Lond. 187: 433-434

Whittenbury, R. (1964). Hydrogen peroxide formation and catalase activity in the lactic acid bacteria. J. gen. Microbiol. 35: 13-26

Williams, A. M., Fryer, J. L., Collins, M. D. (1990). Lactococcus piscium sp. nov. a new Lactococcus species from salmonid fish. Microbiol. Letters 68: 109-114 